\title{
Success Factors and Benefits of Six Sigma Implementation in Hospitals: A Systematic Review
}

\author{
Rashid M. Alhamali \\ Correspondence: Rashid M. Alhamali, College of Business Administration King Saud University, Riyadh, Saudi Arabia.
}

Received: May 5, 2019

doi:10.11114/bms.v5i3.4245
Accepted: May 28, 2019

Online Published: June 5, 2019

URL: https://doi.org/10.11114/bms.v5i3.4245

\begin{abstract}
This review explores critical success factors of Six Sigma implementation in hospitals and identifies the benefits. Data sources and Methodology: Prior studies on Six Sigma (SS) totaling 100 were selected from more than 100 journals. These studies came from numerous databases and are classified based on the year of publication. Journal names with corresponding number of papers selected are reported. The review reveals 25 critical success factors (CSF) necessary in the implementation of Six Sigma, encompassing numerous aspects of an organization such as managerial, statistical, and technical aspects. Twenty benefits derived from SS's implementation are identified, including various improvements in terms of the organizations' processes, financial performance, and quality of service. The success of Six Sigma implementation depends on several critical factors, some of which are best considered before its introduction, while others must be addressed during the process itself. Other factors are external and should be considered during and after its implementation. Not all Six Sigma initiatives are successful nor result in great benefits. Therefore, organizations must analyze their need for Six Sigma projects and base their decisions on the availability/presence of the CSF. Organizations, including hospitals, can gain numerous benefits from Six Sigma implementation but must first evaluate Six Sigma's introduction and implementation against their abilities to achieve desired outcomes.
\end{abstract}

Keywords: Six Sigma, critical success factor, quality, hospital

\section{Introduction}

Six Sigma (SS) was introduced in the late 1980s at Motorola and applied by numerous pilot industrial organizations like General Electric, Du Pont, and Ford (Feng \& Manuel, 2008) as well as American Express, Boeing, Johnson and Johnson, Texas Instruments, and Sony, among others (Nakhai and Neves, 2009). For Motorola, SS was an approach to foster improvements (Heavey, C. and Murphy, E., 2012). (Antony et al., 2007) pointed out that majority of service organizations in the United Kingdom practice SS. Many other studies reported acceptable levels of SS implementation by organizations in different countries. According to (Narula \& Grover, 2013) sigma, a Greek letter, refers to standard deviation, and SS is a methodology used to reduce defects that any process encounters to less than 3.4 defects per one million opportunities. That is, all items produced in accordance with SS meet desired specifications (Dinesh, T. et al., 2013).

An integration of SS with quality was proposed by (Al Khamisi et al. 2018), otherwise known as Lean Six Sigma (LSS). Two major tasks are involved in the introduction of SS. First is to identify defects and variations in the manufacturing process. Second is to lessen these variations to its lowest level (Udayai, K. \& Kumar, P. 2012), (Prasad \& Prajapati, 2014) stated that SS refers to statistical tools that can be used by organizations for purposes of process measurements, analysis, improvement, and control. The ultimate objective of SS is to help produce high quality products.

Difference results of implementing SS have been presented in the literature such as cultural change, cost reduction, and customer retention (Ertürk, M., Tuerdi, M., \& Wujiabudula, A. 2016), (Tjahjono et al. 2010) added that the scope of SS is expanded to cover issues like understanding customer needs, productivity enhancement, and organizational performance improvement. SS deployment has increased after the adoption of this methodology by General Electric (GE) in the mid-1990s (Nakhai and Neves, 2009) . It was implemented in different domains such as banks (Salaheldin, S. I. \& Abdelwahab, I. S., 2009), manufacturing companies (Gosnik, D., \& Vujica-Herzog, N., 2010), home appliance companies retention (Ertürk, M., Tuerdi, M., \& Wujiabudula, A. 2016), service organizations, (Antony et al., 2007), hospitals, and other healthcare settings. According to (Antony et al. 2007), the main purpose of SS implementation in service organizations is to identify the root causes of defects, so as to eliminate these defects to achieve the ultimate goal that is customer satisfaction.

Researchers studied SS in terms of its definition, techniques, benefits, critical success factors, obstacles, and its relationships 
with other constructs. Some examples of these studies encompassed the impact of knowledge management on SS (Furterer, S. L. , 2011) success factors of SS in hospitals (Hilton, R., Balla, M. \& Sohal, A. S., 2008), the influence of SS on organizational performance (Ertürk, M., Tuerdi, M., \& Wujiabudula, A., 2016), the use of SS to improve operations in hospitals (Van den Heuvel, J., Does, R. J., Bogers, A. \& Berg, M., 2006), (Yeh, H. L., Lin, C. S., Su, C. T. \& Wang, P. C., 2011), implementation of SS in service organizations (Antony, J., Jiju Antony, F., Kumar, M. \& Rae Cho, B., 2007), integration of SS with ISO9001 (Marques, P., Requeijo, J., Saraiva, P. \& Frazao-Guerreiro, F., 2013), the use of SS to improve quality of patient care(Antony, J., Palsuk, P., Gupta, S., Mishra, D. \& Barach, P., 2018), (Celano, G., Costa, A., Fichera, S. and Tringali, G., 2012), implementation of SS in hospitals to reduce costs (Niemeijer et al., 2012), and the use of SS in cardiac medication administration to enhance quality of care (Elberfeld, A., Goodman, K. \& Van Kooy, M., 2004).

With respect to findings in the literature, (Shanmugaraja, M., Nataraj, M. \& Gunasekaran, N., 2013) stated that the implementation of SS is limited by the integration of SS and its critical success factors (CSFs). (Tjahjono, B., 2010) indicated that the main critical success factor of SS implementation is the commitment and involvement of top management. Examples of factors required to successfully adopt SS include customer and process focus, management by fact, clear objectives, and vision of top management (Caulcutt, R., 2001). According to (Shokri, A., Oglethorpe, D. \& Nabhani, F., 2014), top management support and employees' acceptance to change are key CSFs of SS adoption. In some cases, the benefits of SS were not as it should be. For example, (Niemeijer et al., 2012) indicated that the implementation of LSS in a medical center in Netherlands did not improve the financial health of the center but transformed it to a process- rather than a problem-oriented center. Several CSFs necessary for SS implementation are elaborated in the following sections of this paper.

As a consequence of SS implementation, organizations are able to improve quality, reduce waste, reduce costs related to rework, and increase customer satisfaction and loyalty (Tjahjono, B., 2010). (Narula, V. \& Grover, S., 2013) stated that General Electric (GE) invested 500 million US dollars in implementing SS and gained at least 2 billion US dollars as a result of its implementation. (Yeh, H. L., Lin, C. S., Su, C. T. \& Wang, P. C., 2011) reported numerous benefits of SS implementation in healthcare such as medical process improvement, increased efficiency of process cycle, decreased days of stay in hospital, and increased competitiveness of hospitals. (Sahbaz, I. et. al., 2014) confirmed that SS was used to help improve quality and performance of several processes in different healthcare departments. (Maleki, M., Riahi, L., Dashti, T. \& Karbasian, S. 2014) revealed that reduced waiting time for surgeries was a primary result of implementing SS in hospitals. Heuvel (Van den Heuvel, J., Does, R. J., Bogers, A. \& Berg, M., 2006) praised the implementation of SS for its contribution to innovative healthcare services. (Akifuddin, S. \& Khatoon, F. 2015) confirmed that the application of SS in the healthcare sector improved hospital management and increased patients' satisfaction. (El-Eid, G., Kaddoum, R., Tamim, H. \& Hitti, E. A. 2015 ) indicated that the application of SS in hospitals results in improved hospital discharge. Contrary to these results, (Kumar, M., Antony, J., Madu, C., Montgomery, D. \& Park, S., 2008) suggested that SS is useful for processes related to goods, not services (De Carvalho, M., Ho, L. \& Pinto, S., 2014) indicated that non-SS approaches have greater influence on quality rather than SS methodology.

Based on above results, this study cites the most reported CSFs and benefits of SS implementation in different industries, with an emphasis on healthcare settings. (Woodard, T. D., 2005) cited SS as the latest quality improvement initiative taken in hospitals to reduce variations and eliminate defects. In the same context, SS was regarded as one of the most important tools for quality improvement in the healthcare sector (Varkey, P., Reller, M. K. \& Resar, R. K., 2007). The quality of healthcare has a special significance as compared to that of other types of services since healthcare services relate to the health of human beings (Sreedharan, V. R. \& Raju, R., 2016). As such, this research's specific objectives are to identify the most common critical success factors of six sigma implementation and to determine the most important benefits of six sigma adoption in different organizations, particularly healthcare settings.

\section{Methodology}

To meet the objectives stated in the introduction, a systematic literature review, described as follows, was conducted using 100 studies previously published in more than 100 journals for the period from 2000 to 2018.

\subsection{Research Strategy}

In their systematic review of LSS, (Nonthaleerak, P. \& Hendry, L., 2006) used a methodology involving three main steps: first, to collect papers from various databases; second, to classify papers based on specific criteria such as methodology, country of research, type of industry, and year of publication; and third, to group papers under certain specifications (such as the particular journals and types of methodologies) as a preliminary way to systematically analyze the papers. (Tjahjono, B., 2010) conducted a review of SS literature from 2004 to 2009. Their research methodology included the following steps: first, determining the appropriate databases and keywords and second, analyzing papers in terms of criteria such as definitions, implementation, tools, benefits, adoption, enablers, and links of SS with other disciplines.

(Nonthaleerak, P. \& Hendry, L., 2006) reviewed more than two hundred papers using two major classifications of SS literature, with an emphasis on research contents and methods. The classification of research content underlined methodology focus (i.e., 
SS concepts, comparison, and enhancement) in addition to implementation focus (i.e., business type, CSFs, and business performance). (Ahmed, S., Manaf, N. H. \& Islam, R., 2013) reviewed the literature on LSS to explore the application of this approach and determine the main effects of LSS on services delivered in healthcare settings. Their review discussed the benefits of using LSS, the healthcare processes where LSS can be applied, and the obstacles of LSS application in healthcare services. Based on the above studies, this systematic review of SS literature identifies the critical success factors of SS, together with the benefits derived from its implementation.

\subsection{Criteria for Article Inclusion}

Papers were included in this review based on their relevance to this review's objectives. Specifically, the papers selected mainly focused on SS or LSS. Papers on LSS were included in this review due to LSS's positive influence on healthcare quality improvement (DelliFraine, J. L., Langabeer, J. R. \& Nembhard, I. M., 2010), (Trakulsunti, Y. and Antony, J., 2018), particularly when derived from SS methodology (Dumitrescu, C. D., Tent, I. D. \& Dumitrescu, E. C. I., 2010). Papers used in this review were also limited to those published in refereed journals.

\subsection{Studies Selected}

The initial number of papers retrieved from numerous databases was 250 papers. Only 100 publications were used in this review in accordance with the stated inclusion criteria. Table 2 shows a list of authors with their studies' respective publication years from 2000 to 2018 .

\section{Results}

The review reveals 25 critical success factors (CSF) necessary in the implementation of Six Sigma, encompassing numerous aspects of an organization such as managerial, statistical, and technical aspects. Twenty benefits derived from SS's implementation are identified, including various improvements in terms of the organizations' processes, financial performance, and quality of service.

\subsection{CSF of Six Sigma}

Using a sample of 200 service organizations in the United Kingdom, Antony et al. (Antony, J., Jiju Antony, F., Kumar, M. \& Rae Cho, B., 2007) explored the benefits, challenges, and CSFs of SS. Their results identified 13 critical factors necessary for the successful deployment of SS. Out of those CSFs, seven factors were ranked as very important. (Tjahjono, B., 2010) conducted a literature review to identify what SS is, what its applications, success factors, and obstacles are, and to determine the emerging trends of SS. They found some critical factors of SS implementation such as top management commitment, training, linkage between SS and information technology experience, and harmonization of human resource practices with SS.

(Narula, V. \& Grover, S., 2013) indicated that other CSFs include commitment of top management, customer and process focus, faster completion of projects, clear measure of success, and the importance of infrastructure available for SS project leaders and workers. (Caulcutt, R., 2001) considered clear objectives and vision of top management, "green and black belts" (SS project leaders), and management by fact as some of the important factors required for SS adoption. (Alkubaisi, M., 2013) specified leadership, champions that are responsible for the development of SS, "green and black belts," as well as tools such as DMAIC (define, measure, analyze, improve, and control) and DMADV as principal requirements of SS implementation. (Habidin, N. \& Yusof, S. R., 2013) identified three dimensions as key success factors of SS: strategic (top management role, a shared vision of the methodology and expectations, learning and training, and SS culture), tactical (dynamics of SS project selection, benchmarking, and continuous control), and operational (The DMAIC approach).

For (Shokri, A., Oglethorpe, D. \& Nabhani, F., 2014), top management support and employees' acceptance of change positively enhance the successful implementation of SS. In a study conducted on Brazilian companies, (De Carvalho, M., Ho, L. \& Pinto, S., 2014) suggested three CSFs of SS implementation, namely, organizational (commitment and resources), infrastructure-related (information systems and statistical tools), and human resource dimensions (internal factors related to employees such as their education and training, and external factors such as consultants). (Niemeijer et al., 2012) confirmed the importance of green and black belt leaders for SS implementation in hospitals due to the fact that the assessment of processes for improvement is a special skill not normally possessed by healthcare staff. (Habidin, N. \& Yusof, S. R., 2013) explored CSFs of LSS in the automotive industry in Malaysia. Their findings showed that leadership and customer focus are the most critical success factors of LSS. Table 1 shows a list of CSFs found in the literature. 
Table 1. Examples of CSFs of Six Sigma found in the literature

\begin{tabular}{|c|c|c|}
\hline No. & Crucial and very important CSFs of SS deployment & Author (s) \\
\hline 1 & Focus on customers and processes & \multirow{24}{*}{$\begin{array}{l}\text { Caulcutt (2001), Antony and Banuelas } \\
\text { (2002), Woodard (2005), Van Den } \\
\text { Heuvel et al. (2005), Nonthaleerak and } \\
\text { Hendry (2006), Antony et al. (2007), } \\
\text { Hilton et al. (2008), Nakhai and Neves } \\
\text { (2009), Tjahjono et al. (2010), Allen et } \\
\text { al. (2010), DelliFraine et al. (2010), } \\
\text { AlSagheer et al. (2011), Mandahawi et } \\
\text { al. (2011), Arumugam et al. (2012), } \\
\text { Celano et al. (2012), Kapoor et al. } \\
\text { (2012), Niemeijer et al. (2012), Habidin } \\
\text { and Yusof (2013), Alkubaisi (2013), } \\
\text { Narula and Grover (2013), Shokri et al. } \\
\text { (2014), Öztürker et al. (2014), De } \\
\text { Carvalho et al. (2014), Jacobs et al. } \\
\text { (2015) and Varma and Ravi (2017), } \\
\text { Trakulsunti and Antony (2018), } \\
\text { Improta et al. (2018). }\end{array}$} \\
\hline 2 & Harmonization of human resource practices with SS & \\
\hline 3 & Linkage between SS and business strategy & \\
\hline 4 & Linkage between SS and information technology experience & \\
\hline 5 & Linkage between SS implementation and financial accountability & \\
\hline 6 & Infrastructure for SS leaders and workers & \\
\hline 8 & Top management commitment, support, and involvement & \\
\hline 9 & Project management skills & \\
\hline 10 & Six Sigma training and experience & \\
\hline 11 & Understanding of SS methodology & \\
\hline 12 & Clear measure of success & \\
\hline 13 & Human resource practices (training, education, and incentives) & \\
\hline 14 & Reduced levels of organizational structure & \\
\hline 15 & Employees' acceptance of change and empowerment & \\
\hline 16 & Effective organizational communication & \\
\hline 17 & Employee recognition and team psychological safety & \\
\hline 18 & "Green and black belt" leaders & \\
\hline 19 & Clear objectives and vision of top management & \\
\hline 20 & Access to expert knowledge of SS & \\
\hline 21 & Shared vision of SS methodology and benefits & \\
\hline 22 & Establishment of SS culture & \\
\hline 23 & Benchmarking & \\
\hline 24 & Financial resources & \\
\hline 25 & Continuous control to ensure successful implementation of SS & \\
\hline
\end{tabular}

3.2 Benefits of Six Sigma

Research on the application of SS revealed significant benefits that result from the adoption and implementation of this innovative approach by organizations in different sectors and specifically, healthcare. (Prasad, P. \& Prajapati, D., 2014) underlined that the main focus of SS is to ensure quality of products and services at a specific target. (Swink, M. \& Jacobs, B. W., 2012) assessed the impact of SS adoption on the financial performance of more than 400 firms and revealed SS adoption's important role in improving organizations' return on assets, indicating that positive impact came from reductions in indirect costs.

(Yeh, H. L., Lin, C. S., Su, C. T. \& Wang, P. C., 2011) found that the application of SS in a hospital resulted in improved medical quality and competitiveness. (Feng, Q., \& Manuel, C. M., 2008) reported some benefits of SS implementation in healthcare such as improvement of quality of care, reduction of medical errors, as well as improvement of patient satisfaction. Moreover, in their investigation of SS implementation in health organizations in the United States, the authors concluded that SS can be implemented in different departments within the organization in a project-oriented fashion to reduce the cycle time, improve flow of processes, and reduce medical errors. (Antony, J., Jiju Antony, F., Kumar, M. \& Rae Cho, B., 2007) confirmed that SS results in enhanced processes that in turn trigger improvements in customer satisfaction, productivity, organizational profitability, and market share. Particularly, the authors identified that SS implementation in the healthcare sector results in improved radiology throughput and reduced cost of radiology. Another important benefit of SS implementation is a reduction in waiting time during surgeries (Maleki, M., Riahi, L., Dashti, T. \& Karbasian, S. 2014).

One of the most significant benefits of SS implementation as determined by (Narula, V. \& Grover, S., 2013) is the improvement of an organization's financial health. In a study conducted by Tan et al. (2014) on the implementation of 
SS in LASIK Surgeries, SS resulted in a reduced rate of LASIK complications. According to (Hekmatpanah, M., Sadroddin, M., Shahbaz, S., Mokhtari, F. \& Fadavinia, F., 2008), there is a positive and direct relationship between SS implementation and an organization's productivity. A main benefit of SS outlined by (Öztürker, C., et al. 2014) is the reduction of care complications in eye surgeries. (Allen, T. T., Tseng, S. H., Swanson, K. \& McClay, M. A., 2010) confirmed that SS results in an enhanced hospital discharge process. (Mandahawi, N., Al-Araidah, O., Boran, A. \& Khasawneh, M., 2011) investigated the application of LSS and found an improvement in the length of stay in the studied hospital. (Kuwaiti, A. A. \& Subbarayalu, A. V., 2017) assessed the effect of using SS in reducing fall rates of patients in a medical center in Saudi Arabia. Their findings highlighted the importance of SS application in eliminating at least $70 \%$ of patient's fall rates. In terms of cost reduction, (Van den Heuvel, J., Does, R. J., Bogers, A. \& Berg, M., 2006) indicated that the total savings of one hospital as a result of SS adoption was 1.4\$ in 2004.

According to (Zafiropoulos, G., 2015), SS can be used to improve doctors' performance, service safety, and patients' needs. An important benefit of SS implementation in hospitals is an increase in the predictability of operations' start time (Fairbanks, C. B., 2007). (Trakulsunti \& Antony, 2018) found that LSS process resulted in numerous benefits such as reduction of medication errors, improvement in patient satisfaction, and reduction in operational costs. In their study on a university hospital in Italy (Improta, G., Cesarelli, M., Montuori, P., Santillo, L. C. \& Triassi, M., 2018) determined LSS to be an effective tool in reducing factors that affect the risk of healthcare-associated infections. Table 2 shows examples of benefits resulting from the application of SS. The table shows 20 benefits of SS application in hospitals related to hospitals, physicians, medical staff, patients, and processes.

Table 2. Examples of benefits of Six Sigma found in the literature

\begin{tabular}{lll}
\hline No. & Benefits of SS application & Author (s) \\
\hline 1 & Improved quality of care & $\begin{array}{l}\text { De Koning et al. (2005), van den Heuvel et al. } \\
\text { (2006), Lee and Choi (2006), De Mast (2006), }\end{array}$ \\
3 & Increased competitiveness & Antony et al. (2007), Hekmatpanah et al. (2008), \\
4 & Reduced waiting time for surgeries & Feng and Manuel (2008), Gowen III et al. (2008), \\
5 & Reduced costs & Chen et al. (2008), Heckl and Moormann (2009), \\
6 & Eeduced medical and non-medical errors in healthcare & Nakhai and Neves (2009), Tjahjono et al. (2010), \\
7 & Improved patient satisfaction & Allen et al. (2010), DelliFraine et al. (2010), Yeh \\
8 & Enhanced data integrity & et al. (2011), Mandahawi et al. (2011), Swinka and \\
9 & Improved medical process & Jacobs (2012), Alkubaisi (2013), Narula and \\
10 & Minimized waste & Grover (2013), Liberatore (2013), Maleki et al. \\
11 & Reduced length of stay in hospitals & (2014), Taner et al. (2014), Shokri et al. (2014), \\
12 & Reduced unnecessary movements & Prasad and Prajapati (2014), Öztürker et al. (2014), \\
13 & Ensuring continuous improvement & Ekinci et al. (2015), Sreedharan et al. (2015), \\
14 & Increased rate of return on investment & Ertürk et al. (2016), Zafiropoulos (2015), Varma \\
15 & Increased satisfaction of patients, physician, and staff & and Ravi (2017) and Al Kuwaiti and Subbarayalu \\
16 & Improved financial health of organization & (2017), Trakulsunti and Antony (2018), Ahmed et \\
17 & Improved organizational productivity & al. (2018), Improta et al. (2018). \\
18 & Improved business performance & \\
19 & Improved process of hospital discharge & \\
20 & Reduced fall rates of patients & \\
\hline 4 & &
\end{tabular}

\section{Discussions}

Quality was first studied as a process in the industrial domain by (Shewhart, W. A., 1931) in order to achieve three major goals, namely, minimization of inspections, determination of customer needs, and reduction of process variations (Varkey, P., Reller, M. K. \& Resar, R. K., 2007). Consequent efforts in the same line can be classified under the category of quality improvement methodologies. There are many approaches that can be followed to improve quality; SS is one of these approaches (Chassin, R., 2008). However, implementing SS in organizations, and more specifically in hospitals, extends the concepts of SS to many other supplementary factors. In the same view, Varma and Ravi [58] defined SS as an approach that depends on a collection of numerous concepts such as managerial, statistical, and technical concepts. According (Celano, G., 
Costa, A., Fichera, S. \& Tringali, G., 2012), SS was adopted early in the healthcare sector in the United States and Europe. (De la Lama et al., 2013) asserted that SS can be used to improve healthcare processes. Based on numerous cases of SS implementation, the authors concluded that the successful implementation of SS in the healthcare sector requires intensive organizational and financial efforts. The literature suggested many factors that represent CSFs of SS implementation. Regarding customers (i.e., patients), the literature identified CSFs that are patient-focused in order to ensure their safety and satisfaction. Meanwhile, hospital-related CSFs suggest management to be distinguished by commitment, support and involvement, with clear objectives and vision; as well as to build an organizational culture that disseminate SS as an improvement tool, introduce continuous control, benchmarking, a shared vision of SS methodology and benefits, and effective organizational communication. Management should pay extensive attention to harmonize human resource practices with SS methodology, linkage between SS and business strategy, as well as information technology experience and financial accountability. Other important factors revealed in the literature concern infrastructure and financial resources, along with access to expert knowledge of SS. Finally, there are several CSFs related to employees such as project management skills, SS training, and experience, acceptance of change, employee empowerment, and trained project leaders (e.g., green and black belt holders). As for the benefits of SS implementation, it is concluded that not all SS projects result in great benefits (Gosnik, D., \& Vujica-Herzog, N., 2010). However, cultivating these CSFs maximizes the likelihood of a successful SS implementation. SS could mean process improvement (Marques, P., Requeijo, J., Saraiva, P. \& Frazao-Guerreiro, F., 2013), through which hospitals can increase their competitiveness, quality of care, patient satisfaction, rate of return on investment, continuous improvement, satisfaction of physician and staff, and simultaneously reduce costs, waiting time for surgeries, medical and non-medical errors, length of stay in hospitals, unnecessary movements, waste, and fall rates of patients. Additionally, the application of SS in hospitals enhances efficiency of physicians, medical processes, organizational productivity, and business performance, and also improves the process of hospital discharge (Jacobs, B. W., Swink, M. \& Linderman, K., 2015) found that organizations that have enhanced financial performance prior to SS application gained better results after its implementation. (Kapoor, A., Bhaskar, R. \& Vo, A., 2012) indicated that a successful SS adoption in healthcare in a case study in India was achieved with the help of information technology applications such as electronic records.

The first step in adopting SS is to conduct a preliminary review of the organization's SS fitness in order to identify the extent to which the organization can improve its current level of quality. According to (Woodard, T. D., 2005), the implementation of SS is not a simple methodology particularly in hospitals; therefore, managers are called to accurately determine their hospitals' abilities to adopt such a methodology. (Alkubaisi, M., 2013) indicated that a cost-benefit analysis is required as an initial step of SS projects. The results of this study identified several CSFs of SS implementations, some of which gained much attention, specifically, management commitment and support. However, only a few studies identified the importance of surgeons' and physicians' support as a key factor of SS implementation in hospitals (Marques, P., Requeijo, J., Saraiva, P. \& Frazao-Guerreiro, F., 2013). Numerous related topics of SS are outside the scope of this study such as SS tools (e.g., process map, Kano analysis, and Ishikawa diagram (Alkubaisi, M., 2013). (Metri, B. A., 2007) showed that SS can be applied at two levels: organization and project levels. The implementation level of SS is outside this study's scope. (Deniz, S., Efe, U., Cimen, M. \& Tekin, Z., 2017) found that there are no differences between hospitals' and banks' managers in terms of their views about SS. Future research could study the topics just mentioned. Additionally, only a few studies investigated the diffusion of SS among local organizations. Hence, exploring this topic is of paramount importance to understand the status of SS implementation in hospitals and compare that to other organizations.

\section{Conclusion}

The success of Six Sigma implementation depends on several critical factors, some of which are best considered before its introduction, while others must be addressed during the process itself. Other factors are external and should be considered during and after its implementation. Not all Six Sigma initiatives are successful nor result in great benefits. Therefore, organizations must analyze their need for Six Sigma projects and base their decisions on the availability/presence of the CSF. Organizations, including hospitals, can gain numerous benefits from Six Sigma implementation but must first evaluate Six Sigma's introduction and implementation against their abilities to achieve desired outcomes

\section{Acknowledgement}

The author thanks the Deanship of Scientific Research and RSSU at King Saud University for their technical support.

\section{References}

Aboelmaged, M. (2010). Six Sigma quality: A structured review and implications for future research. International Journal of Quality \& Reliability Management, 27(3), 268-317. https://doi.org/10.1108/02656711011023294

Ahmed, S., Abd Manaf, N., \& Islam, R. (2018). Effects of Six Sigma initiatives in Malaysian private hospitals. International Journal of Lean Six Sigma. https://doi.org/10.1108/IJLSS-08-2017-0099.

Ahmed, S., Manaf, N. H., \& Islam, R. (2013). Effects of Lean Six Sigma application in healthcare services: a literature 
review. Reviews on environmental health, 28(4), 189-194. https://doi.org/10.1515/reveh-2013-0015

Akifuddin, S., \& Khatoon, F. (2015). Reduction of complications of local anaesthesia in dental healthcare setups by application of the six sigma methodology: a statistical quality improvement technique. Journal of Clinical and Diagnostic Research: JCDR, 9(12), ZC34. https://doi.org/10.7860/JCDR/2015/16829.6989

Al Khamisi, Y., Hernandez, E., \& Khan, M. (2018). Developing a knowledge-based Lean Six Sigma model to improve leadership's performance in healthcare environment. Proceedings SQM XXVI, 31-42.

Alkubaisi, M. (2013). Statistical quality control (SQC) and Six Sigma methodology: An application of X-Bar chart on Kuwait Petroleum Company. International Journal of Business Administration, 4(3), 61-72. https://doi.org/10.5430/ijba.v4n3p61

Allen, T. T., Tseng, S. H., Swanson, K., \& McClay, M. A. (2010). Improving the hospital discharge process with Six Sigma methods. Quality Engineering, 22(1), 13-20. https://doi.org/10.1080/08982110903344812

AlSagheer, A., \& Mohammed, H. (2011). Applying six sigma to achieve enterprise sustainability: preparations and aftermath of six sigma projects. Journal of Business \& Economics Research, 9(4), 51-58. https://doi.org/10.19030/jber.v9i4.4209

Alsmadi, M., Lehaney, B., \& Khan, Z. (2012). Implementing Six Sigma in Saudi Arabia: An empirical study on the fortune 100 firms. Total Quality Management \& Business Excellence, 23(3-4), 263-276. https://doi.org/10.1080/14783363.2011.637814

Antony, J., \& Banuelas, R. (2002). Key ingredients for the effective implementation of Six Sigma program. Measuring Business Excellence, 6(4), 20-27. https://doi.org/10.1108/13683040210451679

Antony, J. (2006). Six sigma for service processes. Business Process Management Journal, 12(2), 234-248. https://doi.org/10.1108/14637150610657558

Antony, J., Jiju Antony, F., Kumar, M., \& Rae Cho, B. (2007). Six sigma in service organizations: Benefits, challenges and difficulties, common myths, empirical observations and success factors. International journal of quality \& reliability management, 24(3), 294-311. https://doi.org/10.1108/02656710710730889

Antony, J., Palsuk, P., Gupta, S., Mishra, D., \& Barach, P. (2018). Six Sigma in healthcare: a systematic review of the literature. International Journal of Quality \& Reliability Management, 35(5), 1075-1092. https://doi.org/10.1108/IJQRM-02-2017-0027

Arumugam, V., Antony, J., \& Kumar, M. (2013). Linking learning and knowledge creation to project success in Six Sigma projects: An empirical investigation. International Journal of Production Economics, 141(1), 388-402. https://doi.org/10.1016/j.ijpe.2012.09.003

Caulcutt, R. (2001). Why is Six Sigma so successful? Journal of Applied Statistics, 28(3-4), 301-306. https://doi.org/10.1080/02664760120034045

Celano, G., Costa, A., Fichera, S., \& Tringali, G. (2012). Linking Six Sigma to simulation: a new roadmap to improve the quality of patient care. International journal of health care quality assurance, 25(4), 254-273. https://doi.org/10.1108/09526861211221473

Chassin, R. (2008). The six sigma initiative at Mount Sinai medical center. Mount Sinai Journal of Medicine: A Journal of Translational and Personalized Medicine, 75(1), 45-52. https://doi.org/10.1002/msj.20011

De Carvalho, M., Ho, L., \& Pinto, S. (2014). The Six Sigma program: an empirical study of Brazilian companies. Journal of Manufacturing Technology Management, 25(5), 602-630. https://doi.org/10.1108/JMTM-04-2012-0045

De la Lama, et al. (2013). Using Six Sigma tools to improve internal processes in a hospital center through three pilot projects. International Journal of Healthcare Management, 6(3), 158-167. https://doi.org/10.1179/2047971913Y.0000000044

DelliFraine, J. L., Langabeer, J. R., \& Nembhard, I. M. (2010). Assessing the evidence of Six Sigma and Lean in the health care industry. Quality Management in Healthcare, 19(3), 211-225. https://doi.org/10.1097/QMH.0b013e3181eb140e

Deniz, S., Efe, U., Cimen, M., \& Tekin, Z. (2017). The perspectives of banking and health sector administrators regarding the Six Sigma approach. Management Science Letters, 7, 241-246.

https://doi.org/10.5267/j.msl.2017.2.002

Dinesh, T. A., Singh, S., Nair, P., \& Remya, T. R. (2013). Reducing waiting time in outpatient services of large 
university teaching hospital-A six sigma approach. Management in health, 17(1), 31-37.

Dumitrescu, C. D., Tent, I. D., \& Dumitrescu, E. C. I. (2010). Lean six sigma principles. Annals of DAAAM \& Proceedings, 21(1), 433-435.

Elberfeld, A., Goodman, K., \& Van Kooy, M. (2004). Using the Six Sigma approach to meet quality standards for cardiac medication administration. Journal of Clinical Outcomes Management, 11(8), 510-516.

El-Eid, G., Kaddoum, R., Tamim, H., \& Hitti, E. A. (2015). Improving hospital discharge time: a successful implementation of six sigma methodology. Medicine, 94(12), 1-18. https://doi.org/10.1097/MD.0000000000000633

Ertürk, M., Tuerdi, M., \& Wujiabudula, A. (2016). The effects of six sigma approach on business performance: A study of white goods (home appliances) sector in turkey. Procedia-Social and Behavioral Sciences, $229,444-452$. https://doi.org/10.1016/j.sbspro.2016.07.154

Fairbanks, C. B. (2007). Using Six Sigma and Lean methodologies to improve OR throughput. Aorn Journal, 86(1), 73-82. https://doi.org/10.1016/j.aorn.2007.06.011

Feng, Q., \& Manuel, C. M. (2008). Under the knife: a national survey of six sigma programs in US healthcare organizations. International Journal of Health Care Quality Assurance, 21(6), 535-547. https://doi.org/10.1108/09526860810900691

Furterer, S. L. (2011). Applying lean six sigma to reduce linen loss in an acute care hospital. International Journal of Engineering, Science and Technology, 3(7), 39-55. https://doi.org/10.4314/ijest.v3i7.4S

Gosnik, D., \& Vujica-Herzog, N. (2010). Success factors for six sigma implementation in Slovenian manufacturing companies. Advances in production engineering \& management, 5(4), 205-216. https://doi.org/10.2478/v10051-009-0011-4

Gowen Iii, C. R., Stock, G. N., \& McFadden, K. L. (2008). Simultaneous implementation of Six Sigma and knowledge management in hospitals. International Journal of Production Research, 46(23), 6781-6795. https://doi.org/10.1080/00207540802496162

Habidin, N., \& Yusof, S. R. (2013). Critical success factors of Lean Six Sigma for the Malaysian automotive industry. International Journal of Lean Six Sigma, 4(1), 60-82. https://doi.org/10.1108/20401461311310526

Heavey, C., \& Murphy, E. (2012). Integrating the balanced scorecard with six sigma. The TQM Journal, 24(2), 108-122. https://doi.org/10.1108/17542731211215062

Hekmatpanah, M., Sadroddin, M., Shahbaz, S., Mokhtari, F., \& Fadavinia, F. (2008). Six Sigma process and its impact on the organizational productivity. World Academy of Science, Engineering and Technology, 43, 365-369.

Hilton, R., Balla, M., \& Sohal, A. S. (2008). Factors critical to the success of a Six-Sigma quality program in an Australian hospital. Total Quality Management, 19(9), 887-902. https://doi.org/10.1080/14783360802224396

Improta, G., Cesarelli, M., Montuori, P., Santillo, L. C., \& Triassi, M. (2018). Reducing the risk of healthcare-associated infections through Lean Six Sigma: The case of the medicine areas at the Federico II University Hospital in Naples (Italy). Journal of evaluation in clinical practice, 24(2), 338-346. https://doi.org/10.1111/jep.12844

Jacobs, B. W., Swink, M., \& Linderman, K. (2015). Performance effects of early and late Six Sigma adoptions. Journal of Operations Management, 36, 244-257. https://doi.org/10.1016/j.jom.2015.01.002

Kapoor, A., Bhaskar, R., \& Vo, A. (2012). Pioneering the health care quality improvement in India using Six Sigma: A case study of a northern India hospital. Journal of Cases on Information Technology, 14(4), 41-55. https://doi.org/10.4018/jcit.2012100104

Kumar, M., Antony, J., Madu, C., Montgomery, D., \& Park, S. (2008). Common myths of six sigma demystified. International Journal of Quality \& Reliability Management, 25 (8), 878-95. https://doi.org/10.1108/02656710810898658

Kuwaiti, A. A., \& Subbarayalu, A. V. (2017). Reducing patients' falls rate in an Academic Medical Center (AMC) using Six Sigma "DMAIC" approach. International journal of health care quality assurance, 30(4), 373-384. https://doi.org/10.1108/IJHCQA-03-2016-0030

Maleki, M., Riahi, L., Dashti, T., \& Karbasian, S. (2014). Reducing waiting time in patients undergone spinal surgeries at operation's room of Shohada-ye-Tajrish hospital using six sigma model. New York Science Journal, 6(12), 136-41.

Mandahawi, N., Al-Araidah, O., Boran, A., \& Khasawneh, M. (2011). Application of Lean Six Sigma tools to minimize 
length of stay for ophthalmology day case surgery. International Journal of Six Sigma and Competitive Advantage, 6(3), 156-172. https://doi.org/10.1504/IJSSCA.2011.039716

Marques, P., Requeijo, J., Saraiva, P., \& Frazao-Guerreiro, F. (2013). Integrating six sigma with ISO 9001. International Journal of Lean Six Sigma, 4(1), 36-59. https://doi.org/10.1108/20401461311310508

Metri, B. A. (2007). Measuring corporate performance with the Six Sigma business scorecard. Vision, 11(3), 59-65. https://doi.org/10.1177/097226290701100306

Nakhai, B., \& Neves, J. S. (2009). The challenges of six sigma in improving service quality. International Journal of Quality \& Reliability Management, 26(7), 663-684. https://doi.org/10.1108/02656710910975741

Narula, V., \& Grover, S. (2013). Six sigma and pitfalls of TQM. YMCAUST International Journal of Research, 1(1), 88-94.

Niemeijer, G. C., Trip, A., de Jong, L. J., Wendt, K. W., \& Does, R. J. (2012). Impact of 5 years of lean six sigma in a University Medical Center. Quality Management in Healthcare, 21(4), 262-268. https://doi.org/10.1097/QMH.0b013e31826e74b7

Nonthaleerak, P., \& Hendry, L. (2006). Six Sigma: literature review and key future research areas. International Journal of Six Sigma and Competitive Advantage, 2(2), 105-161. https://doi.org/10.1504/IJSSCA.2006.010111

Öztürker, C., Şahbaz, İ., Öztürker, Z. K., Taner, M. T., Bayraktar, Ş., \& Kağan, G. (2014). Development of a Six Sigma infrastructure for trabeculectomy process. American Journal of Operations Research, 4(04), 246. https://doi.org/10.4236/ajor.2014.44024

Prasad, P., \& Prajapati, D. (2014). Six Sigma-DMAIC approach of quality improvement: a review. International Journal of Management, IT and Engineering, 4(10), 528-546.

Rohini, R., \& Mallikarjun, J. (2011). Six Sigma: Improving the quality of operation theatre. Procedia - Social and Behavioral Sciences, 25, 273-280. https://doi.org/10.1016/j.sbspro.2011.10.547

Sahbaz, et al. (2014b). Deployment of Six Sigma methodology in phacoemulsification cataract surgery. International Review of Management and Marketing, 4(2), 123-131. https://doi.org/10.14738/abr.22.173

Şahbaz, İ., Taner, M. T., Şahandar, Ü. T., Kağan, G., \& Erbaş, E. (2014a). Elimination of post-operative complications in penetrating keratoplasty by deploying Six Sigma. American Journal of Operations Research, 4(04), 189-196. https://doi.org/10.4236/ajor.2014.44018

Salaheldin, S. I., \& Abdelwahab, I. S. (2009). Six Sigma practices in the banking sector in Qatar. Global Business and Management Research: An International Journal, 1(1), 23-35.

Sen, P. (2015). Application of ANN in Six Sigma for CO modelling and energy efficiency of blast furnace: a case study of an Indian pig iron manufacturing organisation. International Journal of Six Sigma and Competitive Advantage, 9(2-4), 109-125. https://doi.org/10.1504/IJSSCA.2015.074957

Shanmugaraja, M., Nataraj, M., \& Gunasekaran, N. (2013). Total performance excellence-A model for successful implementation of Six Sigma. International Journal of Procurement Management, 6(3), 297-328. https://doi.org/10.1504/IJPM.2013.053651

Shewhart, W. A. (1931). Economic control of quality of manufactured product. Oxford, England: Van Nostrand.

Shokri, A., Oglethorpe, D., \& Nabhani, F. (2014). Evaluating six sigma methodology to improve logistical measures of food distribution SMEs. Journal of Manufacturing Technology Management, 25(7), 998-1027. https://doi.org/10.1108/JMTM-12-2012-0114

Sreedharan, V. R., \& Raju, R. (2016). A systematic literature review of Lean Six Sigma in different industries. International Journal of Lean Six Sigma, 7(4), 430-466. https://doi.org/10.1108/IJLSS-12-2015-0050

Swink, M., \& Jacobs, B. W. (2012). Six Sigma adoption: Operating performance impacts and contextual drivers of success. Journal of Operations Management, 30(6), 437-453. https://doi.org/10.1016/j.jom.2012.05.001

Tjahjono, et al. (2010). Six Sigma: A literature review. International Journal of Lean Six Sigma 2010, 1(3), $216-233$. https://doi.org/10.1108/20401461011075017

Trakulsunti, Y., \& Antony, J. (2018). Can Lean Six Sigma be used to reduce medication errors in the health-care sector? Leadership in Health Services, 31(4), 426-433. https://doi.org/10.1108/LHS-09-2017-0055

Udayai, K., \& Kumar, P. (2012). Implementing Six Sigma to improve hospital discharge process. International Journal of Pharmaceutical Sciences and Research, 3(11), 4528-4532. 
https://doi.org/10.13040/IJPSR.0975-8232.3(11).4528-32

Van den Heuvel, J., Does, R. J., Bogers, A., \& Berg, M. (2006). Implementing six sigma in the Netherlands. The Joint Commission Journal on Quality and Patient Safety, 32(7), 393-399. https://doi.org/10.1016/S1553-7250(06)32051-X

Varkey, P., Reller, M. K., \& Resar, R. K. (2007). Basics of quality improvement in health care. Mayo Clinic Proceedings, 82(6), 735-739. https://doi.org/10.4065/82.6.735

Varma, G., \& Ravi, J. (2017). Six Sigma in electronics company: A case study on Samsung. International Journal of Research in Management Studies, 2(5), 12-25.

Woodard, T. D. (2005). Addressing variation in hospital quality: is six sigma the answer?. Journal of Healthcare Management, 50(4), 226-236. https://doi.org/10.1097/00115514-200507000-00005

Yeh, H. L., Lin, C. S., Su, C. T., \& Wang, P. C. (2011). Applying lean six sigma to improve healthcare: An empirical study. African Journal of Business Management, 5(31), 12356-12370. https://doi.org/10.5897/AJBM11.1654

Zafiropoulos, G. (2015). How six sigma methodology improved doctors' performance. Educational Research and Reviews, 10(18), 2590-2598. https://doi.org/10.5897/ERR2015.2356

\section{Copyrights}

Copyright for this article is retained by the author(s), with first publication rights granted to the journal.

This is an open-access article distributed under the terms and conditions of the Creative Commons Attribution license which permits unrestricted use, distribution, and reproduction in any medium, provided the original work is properly cited. 